Relations industrielles

Industrial Relations

\title{
Hommage à David A. Morse, directeur général du Bureau
} International du travail

\section{A Tribute to David A. Morse, Director-General of the International Labor Office}

\section{Gérard Dion}

Volume 24, numéro 4, 1969

URI : https://id.erudit.org/iderudit/028065ar

DOI : https://doi.org/10.7202/028065ar

Aller au sommaire du numéro

\section{Éditeur(s)}

Département des relations industrielles de l'Université Laval

\section{ISSN}

0034-379X (imprimé)

1703-8138 (numérique)

Découvrir la revue

Citer cet article

Dion, G. (1969). Hommage à David A. Morse, directeur général du Bureau International du travail. Relations industrielles / Industrial Relations, 24(4), 657-661. https://doi.org/10.7202/028065ar
Résumé de l'article

À l'occasion du cinquantenaire de l'Organisation internationale du travail, l'université Laval, lors de la collation des diplômes le 18 octobre 1969, a tenu à marquer cet anniversaire - qui coïncidait avec le vingt-cinquième de la fondation de son département de relations industrielles - en décernant un doctorat d'honneur en sciences sociales \{mention relations industrielles) à M. David A. Morse, directeur général du Bureau international du travail. Voici la citation telle que présentée par le professeur Gérard DION.
Tous droits réservés @ Département des relations industrielles de l'Université Laval, 1969
Ce document est protégé par la loi sur le droit d'auteur. L'utilisation des services d'Érudit (y compris la reproduction) est assujettie à sa politique d'utilisation que vous pouvez consulter en ligne.

https://apropos.erudit.org/fr/usagers/politique-dutilisation/ 


\title{
Hommage à David A. Morse,
}

\author{
Directeur général du Bureau international du Travail
}

\begin{abstract}
À l'occasion du cinquantenaire de l'Organisation internationale du travail, l'université Laval, lors de la collation des diplômes le 18 octobre 1969, a tenu à marquer cet anniversaire - qui coïncidait avec le vingt-cinquième de la fondation de son département de relations industrielles - en décernant un doctorat d'honneur en sciences sociales (mention relations industrielles) à $M$. David $A$. Morse, directeur général du Bureau international du travail. Voici la citation telle que présentée par le professeur Gérard DION.
\end{abstract}

M. David A. Morse est originaire de New York. Après avoir terminé ses études à la Harvard Law School, il entra au Barreau de New Jersey en 1932. Pendant les années qui suivirent, il occupa diverses fonctions importantes dont celle de conseiller juridique à l'Office national des relations du travail pour la région de New York. Après la guerre où il servit comme directeur du travail du gouvernement militaire en Sicile, en Italie et en Allemagne, on le retrouve au poste de conseiller juridique de l'Office national des relations du travail aux États-Unis. Il devint ensuite soussecrétaire, secrétaire-adjoint au département du travail et il exerçait la fonction de secrétaire du travail des États-Unis lorsqu'il fut élu en 1948, directeur général du Bureau international du travail, poste qu'il n'a cessé d'occuper depuis lors.

L'Organisation internationale du travail célèbre en 1969 le cinquantième anniversaire de sa fondation.

De tous les organismes internationaux institués par le traité de Versailles, l'O.I.T. est le seul qui, malgré les conflits idéologiques et les affrontements d'intérêts, a réussi en passant à travers toutes les vicissitudes et en surmontant les difficultés, à se maintenir dans la poursuite de son oeuvre et à conserver la confiance universelle. 
Cette survivance qui a eu raison des erreurs et des faillites accumulées par toutes les nations dans le domaine de la politique internationale manifeste autant l'importance permanente des objectifs que s'était assignés l'O.I.T. en voulant être un instrument de paix, de progrès et de justice sociale que la qualité et la nécessité de l'oeuvre positive et progressive qu'elle a réalisée.

Grâce à sa structure tripartite où non seulement les états, mais les représentants des employeurs et ceux des travailleurs peuvent se rencontrer et rechercher ensemble les moyens pour améliorer le sort des travailleurs, l'O.I.T. s'est révélée le plus efficace instrument de collaboration internationale dont les bons effets se sont fait sentir tant dans les pays en voie de développement que dans les pays déjà industrialisés.

Si l'O.I.T. demeure toujours essentiellement une oeuvre de coopération entre les nations qui acceptent librement d'y adhérer et qui, avec les représentants des employeurs et des travailleurs, déterminent ultimement sa politique, le rôle de directeur général est tout à fait primordial. Celui-ci doit faire montre autant d'imagination que de diplomatie, de patience que de fermeté, pour que l'institution conserve une cohésion qui ne se mue pas en paralysie dans des palabres stériles, mais qui garde son élan dynamique et créateur dans l'efficacité.

De tous les directeurs généraux du B.I.T., M. David A. Morse est celui qui a occupé le plus longtemps ce poste de haute responsabilité. A lui seul, il a accumulé presqu'autant d'années de service que ses quatre prédécesseurs pris ensemble. Depuis qu'il a accédé à cette fonction et s'est vu renouvellé à l'unanimité son mandat en 1957, en 1962 et en 1967, l'organisme qu'il dirige a connu une croissance rapide et une évolution graduelle de ses activités et de ses méthodes de travail pour répondre aux besoins nouveaux d'un monde en transformation. Signalons que les 55 états-membres en 1948 sont aujourd'hui passés à 118 et que le personnel de l'O.I.T. s'élève à plus de deux mille fonctionnaires répartis tant au siège social de Genève qu'à travers tout le monde.

Les membres représentent aujourd'hui la plus grande diversité de races et d'idéologies et tout l'éventail des situations sociales, économiques, culturelles et politiques. Devant tenir compte des nécessités et besoins de tous ses membres ainsi que d'essayer de les satisfaire et de les aider dans l'établissement de politiques en matière du travail, l'O.I.T. peut à bon droit être présentée comme un exemple de conciliation entre systèmes 
économiques et politiques différents sans pour cela renoncer à sa philosophie et à ses objectifs qui forment un minimum sur lequel toutes les nations s'entendent: le respect et l'épanouissement de la personne humaine dans sa condition de travailleur. Enfin grâce à la qualité des travaux de recherche exécutés par ses experts et à ses multiples publications qui font autorité, le B.I.T. est certainement l'institution qui a le plus contribué à l'avancement des connaissances dans le domaine des relations du travail.

L'université Laval qui partage les idéaux poursuivis par l'O.I.T. suit de près son oeuvre difficile et bienfaisante pour l'ensemble de l'humanité.

Pendant la dernière guerre mondiale, alors que l'O.I.T. avait été obligée de transférer son siège social ici au Canada, à Montréal, la faculté des sciences sociales avait pu bénéficier de la collaboration de certains membres de son personnel pour assurer un enseignement. Et la présence de l'O.I.T. en terre québécoise n'a pas été étrangère à la création de son département de relations industrielles. En reconnaissance de ces services et pour marquer son appréciation envers le directeur-général du temps, elle accordait en 1945 un doctorat d'honneur à M. Edward Pheelan.

L'université Laval est heureuse encore aujourd'hui, à l'occasion du cinquantième anniversaire de cette institution si méritante et du vingtcinquième anniversaire de la fondation de son propre département de relations industrielles de répéter ce geste en recevant dans son corps de docteurs le grand instigateur de la recherche en relations du travail et l'infatigable artisan de la paix et du développement qu'est le directeur général du Bureau international du travail et président du Conseil de l'Institut international d'études sociales.

J'invite donc M. David A. Morse à revêtir la toge et à recevoir des mains du Recteur le diplôme de docteur en sciences sociales (mention relations industrielles) ainsi qu'à signer le livre d'Or de l'université Laval. 


\title{
A Tribute to David A. Morse,
}

\author{
Director-General of the International Labor Office
}

\begin{abstract}
Last October 18, l'université Laval marked the fiftieth anniversary of the International Labor Organization together with the twenty-fifth anniversary of its Department of Industrial Relations - by awarding David A. Morse, Director-General of the ILO, the degree of doctor "honoris causa" in Social Sciences (in the field of Industrial Relations). The following citation was presented by Professor Gerard DION.
\end{abstract}

Born in New York, Mr David A. Morse graduated from Harvard Law School and was admitted to the bar in New Jersey in 1932. During the following years, he filled various important posts, one as legal adviser to the National Labor Relations Board in the metropolitan area of New York. After his war service as Labor Director for the Military Government in Sicily, Italy and Germany, he was reappointed legal adviser to the National Labor Relations Board in the United States. He then became Assistant-Secretary and Under-Secretary to the Labor Department, and he was Acting-Secretary to the United States Labor Department when he was elected, in 1948, Director-General of the International Labor Office. $\mathrm{Mr}$ Morse still occupies this post.

1969 is the fiftieth anniversary of the International Labor Organization. It must be emphasized that the ILO is the only international organization of all those set up under the Treaty of Versailles which has succeeded in surviving and maintaining universal confidence in spite of numerous ideological disputes and conflicts of interest.

This survival, despite the accumulated errors and failures of all nations in the field of international politics, is manifest proof as much of the permanent importance of the ILO's aims - to be an instrument of peace, progress, and social justice, - as of the quality of and necessity for its progressive and positive action.

States, Employer and Labor representatives can meet and investigate together means of improving the labor situation within the tripartite structure of this international organization. It is because of this structure that the ILO has become the most able instrument of international cooperation whose beneficial effects have been felt equally by developing and industrialized countries. 
Even if the ILO is by definition an organization of cooperation between voluntary member-nations which, together with employer and labor representatives, ultimately determine its own policies, the role of the Director-General is primordial. Diplomacy, imagination, patience, and firmness are the prime qualities of the Director-General which are necessary to insure the organization a coherent, dynamic, and creative character.

Of all the Directors-General of the ILO, David A. Morse is the one who has occupied this Office of high responsibility for the longest time. $\mathrm{He}$ has, in fact, accumulated almost as many years of service as his four predecessors together. Since 1948, his mandate has been unanimously renewed in 1957,1962 , and 1967 . Since then, the ILO has grown rapidly while its activities and methods of work have gradually evolved to face the new needs of a changing world. The number of Member-States has passed from 55 in 1948, to 118 in 1969, while the ILO's staff now counts more than two thousand persons working in Geneva and throughout the world.

The present ILO members represent the greatest diversity of races and ideologies and a whole range of political, cultural, economic and social situations. The ILO must consider the necessities and needs of all its members in order to bring them satisfaction and help in the establishment of labor policies. It is for this reason that one can legitimately present the ILO as an example of effective conciliation between different political and economic systems which nonetheless does not relinguish its philosophy and objectives the minimum accepted by all nations: respect for man's working conditions. In fact, the ILO is without any doubt the greatest contributor to the advancement of knowledge in the field of labor relations due to the quality of the research done by its experts and its numerous authoritative publications.

L'université Laval shares the ILO's ideals and follows with interest the difficult and beneficent work it accomplishes for all mankind.

During the last World War, when the ILO had to move its Head Office here in Canada to Montreal, our Faculty of Social Sciences had the good fortune of benefiting from the collaboration of some of its members who assumed teaching responsibilities. It might be said that the presence of the ILO in Quebec was perhaps one of the factors which contributed to the creation of our Department of Industrial Relations.

As a sign of recognition for these services and of deep appreciation to the Director-General of that time, l'université Laval, in 1945, awarded Edward Pheelan the degree of doctor "honoris causa".

On the occasion of this fiftieth anniversary of the ILO and of the twenty-fifth anniversary of its own Department of Industrial Relations, l'université Laval is proud to receive among its doctors this great instigator of research in Labor Relations, this man devoted to peace and progress, who is Director-General of the ILO and Chairman of the Board of Trustees of the International Institute of Labor Studies. 